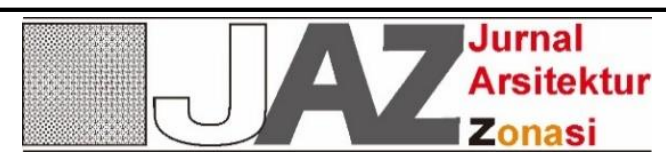

http://ejournal.upi.edu/index.php/jaz - e-mail: jurnal.zonasi@gmail.com dan jurnal_zonasi@upi.edu doi.org/10.17509/jaz.v3i3.25018

\title{
KAJIAN KONSEP ARSITEKTUR SEMIOTIK PADA BANGUNAN GEDUNG PERTUNJUKAN
}

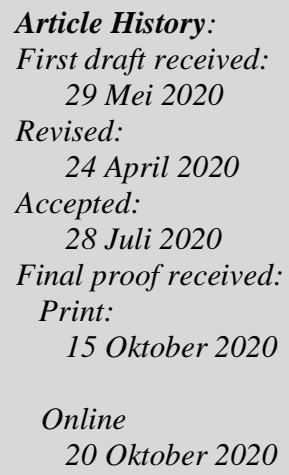

Jurnal Arsitektur ZONASI is indexed and listed in several databases:

SINTA 4 (Arjuna)

GARUDA (Garda Rujukan Digital)

Google Scholar

Dimensions

oneSearch

BASE

Member:
Crossref
RJI
APTARI
FJA (Forum Jurna Arsitektur)
IAI
AJPKM

\author{
Muhammad Luthfi Ibrahim \\ Ashadi $^{2}$ \\ 1,2, Fakultas Teknik Universitas Muhammadiyah Jakarta Prodi Arsitektur, Indonesia. \\ Jl. Cempaka Putih Tengah 27 No.27/10, RT.7/RW.7, Kecamatan Cempaka Putih, Kota \\ Jakarta Pusat, Daerah Khusus Ibukota Jakarta 10510. \\ Email: ${ }^{12016460031 @ f t u m j . a c . i d ~}$ \\ 2ashadi@ftumj.ac.id
}

Abstract: Understanding and recognition of signs in architecture is one of the basic sciences in teaching architecture which is better known by the term semiotic. Recognition of the sign of a building is a form of communication in architecture, and the most easily applied is the physical form / facade of a building. The concept of semiotic architecture harmonizes symbols / signs as a medium of communication to present a reality that occurs in the building and its surroundings. This research method applies descriptive qualitative research, because this research focuses on understanding social phenomena that occur in society. The approach applied in this research is a case study approach (Case Consideration). This approach focuses intensively on a particular object and studies it as a case. The results of the research are the search and determination of index marks in the form of representamen representing objects in the case study and carried out in a tiered manner. Conclusions regarding the application of the concept of semiotic architecture Index Marks in building buildings that have been studied have the form of index signs that appear and are seen in each type of scope, namely: ranging from the scope of the environment, the scope of the building site, the scope of the building outside and inside, and the scope of the elements building

Keywords: Semiotic Architecture, Charles Sanders Peirce, Performance Building

Abstrak: Pemahaman dan pengenalan tanda dalam arsitektur ialah salah satu ilmu dasar dalam pengajaran arsitektur yang lebih diketahui dengan istilah semiotik. Pengenalan tanda dari suatu bangunan merupakan suatu bentuk komunikasi di dalam arsitektur, dan yang paling mudah diterapkan ialah terhadap bentuk fisik/fasade suatu bangunan. Arsitektur semiotik berkonsep menyelaraskan simbol/tanda sebagai media komunikasi untuk menghadirkan sebuah kenyataan yang terjadi pada bangunan maupun di sekitarnya. Metode penelitian ini menerapkan jenis penelitian deskriptif kualitatif, sebab penelitian ini berfokus pada pemahaman terhadap fenomena sosial yang terjadi di masyarakat. Pendekatan yang diterapkan pada penelitian ini merupakan pendekatan studi kasus (Case Consider). Pendekatan ini memfokuskan diri secara intensif pada suatu objek tertentu dan mempelajarinya sebagai suatu kasus. Jenis penelitian ini juga merupakan jenis penelitian dengan sistem melihat fakta-fakta maupun ilustrasi suatu keadaan yang ada dan kemudian dianalisa dengan mendeskripsikan serta mengidentifikasikan setiap aspek yang ada. Hasil penelitian berupa pencarian dan penentuan tanda-tanda indeks berupa representamen yang mewakili objek pada studi kasus dan dilakukan dengan cara berjenjang lingkupnya. Kesimpulan mengenai penerapan konsep arsitektur semiotik Tanda Indeks pada bangunan gedung pertunjukan yang telah dikaji mempunyai bentuk tanda-tanda indeks yang muncul dan terlihat pada setiap jenis lingkupnya yaitu : mulai dari lingkup lingkungan, lingkup tapak bangunan, lingkup bangunan bagian luar maupun dalam, dan lingkup elemen bangunan

Kata Kunci: Arsitektur Semiotik, Charles Sanders Peirce, Gedung Pertunjukan 


\section{Pendahuluan}

Di universitas, arsitektur adalah salah satu disiplin ilmu yang berspesialisasi dalam penelitian seperti disiplin ilmu lainnya. Secara umum, setiap orang dapat memahami dan menjelaskan arsitekturnya. Cara termudah adalah mengamati bentuk objek. Pemahaman arsitektur dipengaruhi oleh kerangka sosial, ekonomi dan budaya dan komunitas lokal di mana objek-objek arsitektur berada. Pemahaman arsitektur juga dipengaruhi oleh ruang lingkup arsitektur, karena secara fisik menentukan persepsi arsitektur.

Memahami dan mengidentifikasi tanda-tanda (sign) dalam arsitektur adalah salah satu ilmu dasar dalam pengajaran arsitektur, dan istilah "semiotika" sudah dikenal luas. Tanda-tanda untuk mengidentifikasi suatu bangunan adalah bentuk komunikasi dalam bangunan, dan yang paling mudah untuk diterapkan adalah bentuk fisik / penampilan bangunan. Ini karena fasad bentuk / bangunan fisik adalah komponen yang secara langsung berinteraksi dengan pengamat dan memberi makna (meaning), dan juga merupakan salah satu cara yang paling komunikatif dalam menerapkan konsep semiotik.

Bangunan yang menerapkan konsep arsitektur semiotik selalu berhubungan erat dengan adanya suatu tanda atau pemaknaan dalam bentuk fisik/fasade maupun motif-motif bangunan itu sendiri. Konsep semiotik banyak diterapkan pada bangunan-bangunan masa lalu maupun sekarang seperti bangunan-bangunan dengan volume yang besar, salah satunya adalah gedung pertunjukan. Selain bertujuan untuk menambah nilai estetika dan keindahan pada tampak bangunan, konsep semiotik juga mengundang rasa keingintahuan masyarakat umum mengenai tanda-tanda yang diaplikasikan pada bangunan itu sendiri.

Konsep arsitektur semiotik sangatlah penting untuk diterapkan pada semua desain jenis bangunan yang ada diseluruh penjuru dunia, khususnya pada bangunan gedung pertunjukan. Hal ini dikarenakan bangunan gedung pertunjukan merupakan suatu wadah ekspresi keindahan manusia melalui penciptaan karya seni. Desain arsitektur semiotik akan menghasilkan suatu rancangan yang lebih spesifik yakni rancangan sebuah gedung pertunjukan yang mengacu pada pertunjukan-pertunjukan seni yang ada di Indonesia.

Dari latar belakang tersebut akan dijabarkan berbagai bentuk dari konsep arsitektur semiotik yang akan timbul pada bangunan gedung pertunjukan. Permasalahan yang timbul di dalam penelitian ini diantaranya ;

1. bagaimana konsep semiotika dalam arsitektur?

2. bagaimana penerapan konsep arsitektur semiotika pada bangunan Gedung Pertunjukan?

Pandangan pertama, berpendapat bahwa pemahaman seseorang terhadap arsitektur tidak sama dipengaruhi oleh latar belakang keluarga, pendidikan, sosial serta budaya orang tersebut. Seseorang dapat tahu "apa itu arsitektur" bisa dilakukan dengan membaca "pertanda" yang terdapat di objek yang dilihatnya. Pembacaan tanda bisa dilakukan dengan pendekatan semiotika yaitu suatu ilmu yang mengkaji perihal pertanda serta petanda yang diperoleh melalui pendidikan arsitektur. (Saraswaty 2016)

Pandangan kedua, berpendapat bahwa pemanfaatan Semiotika pada Arsitektur tradisional minahasa adalah upaya arsitek buat mengajak rakyat awam memahami karyanya dengan cara berkomunikasi. Selain memiliki denotatum utama (Denotasi) yaitu fungsi, karya-karya Arsitektur yang dianggap menjadi indikasi juga memiliki denotatum sekunder (Konotasi) yaitu makna atau pesan yang terkandung. Dalam Semiotika Arsitektur pesan yang terkandung (signified) dalam obyek terbentuk dari korelasi antara pemberi tanda (signifier) serta fungsi nyata atau sifat benda. (Ashadi, 2018)

Penelitian ini mempunyai tujuan yaitu untuk memahami pengertian dari konsep arsitektur semiotik dan memahami penerapan konsep arsitektur semiotik pada bangunan Gedung Pertunjukan.

\subsection{Teori Semiotika Secara Umum}

Semiotika adalah suatu kajian ilmu perihal menganalisis suatu pertanda-pertanda. Dalam kajian semiotika menganggap bahwa kenyataan sosial pada masyarakat dan kebudayaan itu merupakan indikasipertanda. Semiotik itu menyelidiki mengenai metode-metode, aturan-aturan, \& kesepakatan konvensi yang memungkinkan pertanda-indikasi tentang suatu hal demikian memiliki sebuah arti.

Istilah "semiotika" berasal dari istilah Yunani, semeion, yang berarti pertanda. Semiotika berarti ilmu seputar pertanda atau studi perihal pertanda (the study of sign). Semiotika dan semiologi mempunyai arti yang sama yaitu ilmu seputar tanda atau studi perihal tanda. Istilah yang pertama diusung oleh Charles Sanders Peirce, seorang pakar logika, berkebangsaan Amerika, bersama para pendukungnya, dan istilah yang kedua diusung oleh Ferdinand de Saussure, seorang pakar linguistik, berkebangsaan Swiss, bersama para pendukungnya.

Ditunjukkan bahwa setidaknya ada sembilan jenis semiotik, yaitu : 
a) Semiotik Analitik, merupakan semiotik yang menganalisa metode tanda-tanda. Peirce menyampaikan bahwa semiotik berobjekan tanda dan penganalisisnya menjadi inspirasi baru, objek, \& makna. Inspirasi baru bisa dihubungkan sebagai lambang, sedangkan makna ialah muatan yang terdapat dalam lambang yang merujuk terhadap objek tertentu.

b) Semiotik Deskriptif, merupakan semiotik yang mengamati cara tanda yang dapat dialami masa kini.

Contohnya langit yang mendung membuktikan bahwa hujan tak lama lagi akan turun, dari dulu sampai saat ini tetap konsisten dengan keadaan seperti itu. Demikian pula kalau ombak memutih di tengah laut, itu menggambarkan bahwa laut berombak besar. tetapi, dengan majunya ilmu pengetahuan, teknologi, dan seni telah banyak indikasi yang diwujudkan sang insan untuk memenuhi keperluannya.

c) Semiotik Faunal (Zoo Semiotic), merupakan semiotik yang khusus mengamati metode pertanda yang dibuat oleh binatang. Binatang umumnya membentuk indikasi buat berkomunikasi antara sesamanya, namun juga seringkali kali membentuk pertanda yg mampu ditafsirkan sang manusia. Semisal seekor ayam betina yang berkotek-kotek menggambarkan ayam itu sudah bertelor atau terdapat sesuatu yg ditakuti. Tanda-tanda yang dibentuk sang binatang seperti ini, menjadi perhatian orang yang bergerak pada bidang semiotik faunal.

d) Semiotik Kultural, yaitu, semiotik, yang berspesialisasi dalam studi metode semiotik yang berlaku untuk budaya tertentu. Orang-orang telah menyadari bahwa masyarakat, sebagai makhluk sosial, memiliki cara tradisional tertentu dan telah secara turun-temurun dipelihara dan dihormati. Adat termasuk dalam komunitas, yang juga merupakan sistem yang menggunakan pertanda-pertanda tertentu untuk membedakannya dari komunitas lain.

e) Semiotik Naratif, adalah semiotik yg mempelajari metode sebuah tanda dalam narasi yang berwujud mitos \& cerita verbal (folklore). Sudah diketahui bahwa mitos dan cerita verbal, terdapat diantaranya mempunyai nilai kultural yang tinggi.

f) Semiotik Natural, merupakan semiotik yang khusus menganalisa cara indikasi yang diciptakan oleh alam. Contohnya air sungai yang keruh mendeskripsikan pada hulu sudah turun hujan, \& daun pohon-pohonan yang menguning kemudian gugur. Alam yang tak berteman menggunakan insan, semisal banjir atau tanah longsor, hakekatnya memberikan pertanda terhadap manusia bahwa insan sudah merusak alam.

g) Semiotik Normatif, adalah semiotik yg khusus mengkaji tanda yang diciptakan sang manusia yang berwujud etika-etika. Contohnya rambu-rambu lalu lintas. Di ruang kereta barag sering kali ditemui indikasi yang bermakna dilarang menghisap rokok.

h) Semiotik Sosial, adalah semacam semiotik, yang merupakan metode menganalisis simbol-simbol yang dibentuk oleh manusia dalam bentuk simbol (termasuk simbol berwujud atau kata simbolis berwujud), yang disebut kalimat. Contoh buku Halliday (1978) sendiri adalah "Semiotika Sosial Bahasa". Dengan kata lain, semiotika sosial meneliti metode simbolik yang ditemukan dalam bahasa.

i) Semiotik Struktural, dengan kata lain, semiotika secara khusus menganalisis metode simbolik yang diwujudkan melalui struktur bahasa. (Pateda 2001)

Singkatnya (Sobur 2003), semiotika adalah sistem ilmiah atau analitik yang digunakan untuk menganalisis simbol. Simbol di sini adalah peralatan yang mencari metode di dunia ini di antara manusia dan manusia. Semiotika, atau istilah Barhtes, adalah semiotika, yang pada dasarnya ingin mempelajari bagaimana manusia menerapkan sesuatu. Meskipun semiotika didasarkan pada Lechte (dalam Sobur, 2003: 16), semiotika adalah teori seputar simbol dan tanda.

Berger (dalam Sobur, 2003: 18) mengemukakan: "semiotika memusatkan perhatian pada apa pun yang dapat direpresentasikan sebagai simbol. Tanda adalah apa pun yang dapat dianggap sebagai tanda, dan memiliki makna penting lainnya sebagai pengganti. Tidak ada yang lain. Sesuatu, atau tanda itu memang ada di area tertentu pada waktu tertentu. Dengan demikian, semiotik pada prinsipnya adalah disiplin yang mempelajari segala sesuatu yang dapat digunakan untuk mengungkapkan kebohongan. Jika sesuatu seperti ini tidak dapat digunakan untuk berbohong, sebaliknya, Itu tidak bisa mengatakan yang sebenarnya”.

\subsection{Semiotika Menurut Charles Sanders Peirce (1834-1914)}

Menurut Pierce, tandanya bukan struktur, tetapi aktivitas kognitif yang bisa dirasakan oleh indera. Oleh karena itu, semiotika Pierce juga disebut semiotika praktis. Peirce (Peirce) percaya bahwa tanda itu adalah "sesuatu yang mewakili sesuatu". "Benda" atau "konkret" pertama adalah "representasi" yang disebut "representasi" (tanah), meskipun "benda" dalam kognisi disebut objek. Proses hubungan dari representasi ke objek disebut semiotika. Dalam makna simbol, proses simbolisasi belum selesai karena ada proses lain yang berlanjut setelahnya, yang disebut interpreter (proses interpretasi). Oleh karena itu, makna umum simbol muncul dalam bentuk proses simbolisasi, yaitu, dari simbolisasi konkret ke kognisi orang yang hidup dalam masyarakat. Karena sifat semiotika menghubungkan tiga aspek simbol, objek dan juru bahasa, dalam proses 
semiotika, teori semiotika disebut trisection atau trisection.

Berikut beberapa contoh :

- Asap yang kita lihat dalam pengukusan jarak jauh (R) diserap dan ditentukan (atau diekspresikan) pada saat momen kebakaran $(\mathrm{O})$.

- Lukisan yang kita lihat (R) merujuk pada manusia, hewan, atau benda yang diketahui dari (atau mewakili) pikiran (kognisi) manusia (O).

- Lampu merah pada rambu lalu lintas (R) menunjukkan (atau mewakili) konsep "berhenti" (O).

- Pemandu turis mengantarkan sang turis yang berasal dari Amerika menuju monas, lalu dikala sang turis memperhatikan monas, dia bertanya kepada si pemandu "apa yang ada di puncak monas itu?" Si pemandu malah balik bertanya kepada si turis "menurut anda itu apa?" Sang turis menjawab "ice cream". Ketika dijelaskan bahwa yang di atas monas itu "api", sang turis menjadi heran. Menurut pengalaman budayanya, api itu warnanya merah, bukan keemasan. "Monas" berarti hubungan dengan objek "es krim" adalah proses simbolis yang terjadi di antara para wisatawan. Oleh karena itu, "api emas" di puncak Monas mengacu pada pengalamannya: "Jenis hal dalam hidup saya adalah es krim". (dalam Ashadi, 2018 : 126-127)

Proses semiosis tidak hanya terjadi sekali melainkan bisa terjadi berkali-kali, menandakan bahwa satu pertanda dapat membentuk pertanda lain, dan seterusnya.

Berdasarkan relasi antara representamen dengan objeknya, Peirce membedakan tanda-tanda : ikon (sederhana pemaknaannya), indeks (tingkatan kesulitan diantara ikon dan simbol), dan simbol (sulit pemaknaannya).

a) Ikon

Merupakan tanda yang mengandung keserupaan antara representamen dengan objek yang diwakilinya. Ikon dapat dibedakan menjadi tiga jenis: ikon imej atau topologi, ikon diagram, dan ikon metafora.

- Ikon Imej atau Tipologi

Merupakan tanda yang mengandung keserupaan bentuk antara representamen dengan objek yang diwakilinya. Contoh, suatu peta geografis $(\mathrm{R})$ merupakan ikon dari geografi wilayah yang sebenarnya $(\mathrm{O})$.

- Ikon Diagram

Merupakan tanda yang berisi tahapan atau level yang serupa (seperti bagan) dengan objek yang diwakilinya. Sebagai contoh, peringkat militer seperti bintang satu, dua bintang, tiga bintang, dan empat bintang (R) adalah ikon posisi dalam tentara, brigadir jenderal, mayor jenderal, letnan jenderal, dan jenderal $(\mathrm{O})$.

- Ikon Metafora

Merupakan tanda yang mengandung keserupaan yang tidak total sifatnya antara representamen dengan objek yang diwakilinya. Contoh, bunga mawar (R) merupakan ikon dari seorang gadis (O). Keduanya dianggap memiliki keserupaan dalam hal, misalnya kecantikan dan kesegaran, namun keserupaan itu tidak total sifatnya.

b) Indeks

Merupakan tanda yang berisi fenomena atau hubungan ketergantungan yang ada antara representasi dan objek yang diwakilinya. Misalnya, jejak kaki di lahan basah $(R)$ adalah indeks orang $(O)$ yang lewat di sana. Contoh lain, asap (R) adalah indeks pengapian (O). Dari segi arsitektur, contoh lain adalah bahwa keberadaan bangunan masjid yang menjulang $(\mathrm{R})$ adalah indeks keberadaan bangunan masjid $(\mathrm{O})$ tidak jauh dari menara.

\section{c) Simbol}

Adalah tanda keteraturan (persetujuan umum atau persetujuan dari publik) dan kesewenangwenangan (arbitrary, manasuka). Misalnya, lampu lalu lintas dengan tiga warna: hijau berarti berjalan diperbolehkan, merah berarti berjalan dilarang, dan kuning berarti peringatan. Jadi warna hijau lampu rambu lalu lintas merupakan simbol larangan bagi kendaraan untuk berjalan atau melintas; warna hijau merupakan simbol izin bagi kendaraan untuk berjalan atau melintas; warna kuning merupakan simbol hati-hati bagi kendaraan saat sedang berjalan atau melintas. (Ashadi, 2018 : 128-130)

\subsection{Semiotika Dalam Arsitektur}

Dalam era arsitektur post-modern, semiotika sudah banyak diterapkan. Dalam era ini arsitek ingin mengajak masyarakat umum untuk memahami karyanya lewat tanda (ilmu semiotik) dengan sistem berkomunikasi. Semiotika adalah studi tentang simbol. Struktur, tipe-tipe, hubungan simbol, dan 
penggunaannya dalam masyarakat adalah hal-hal yang dipelajari dari semiotik. Menurut Charles Sanders Pierce, kemunculan semiotika adalah karena interaksi antara simbol dan objek, dan interpreter adalah hasil dari interaksi ini. (Jansz 2002)

Semiotika dalam arsitektur memiliki hubungan yang erat antara kondisi geografis, sejarah dan budaya lokal, serta komunitas sosial yang mengelilinginya ketika menggunakan warna, bentuk, ruang, konten / volume dan bahkan permukaan bangunan, karena hubungannya dengan bidang lain Demikian pula, bentuk arsitektur biasanya dapat dikatakan memiliki makna sebelum makna. Selain rumah, jendela juga memiliki konotasi dan konotasi. Arti notasi itu jelas, misalnya maknanya bisa menjelaskan kemegahan bangunan dalam proporsi atau bentuk.

\subsection{Pengertian Gedung Pertunjukan}

Gedung pertunjukan adalah gedung yang memiliki fungsi untuk melayani dan mempromosikan berbagai jenis pertunjukan. Bangunan ini adalah ruang semi-publik yang bertujuan untuk menghibur orang melalui pertunjukan. Bangunan mengacu pada bangunan (rumah) yang digunakan untuk menampilkan prestasi artistik di kantor, pertemuan / tempat. Pertunjukan meliputi pertunjukan (seperti teater film, boneka, boneka, dll.) dan pameran demonstrasi (Poerwadarminta, 1976 : 1108).

Ada beberapa jenis Gedung Pertunjukan. Menurut (Neufert 2002), Gedung Pertunjukan dibagi menjadi beberapa jenis, yaitu :

\section{a) Teater}

Ciri khas bangunan teater adalah ada kursi di lantai pertama (yaitu, penonton duduk di lapangan lebar dalam bentuk kurva naik / naik), dan melalui bagian depan panggung yang terlihat jelas, bagian depan panggung dapat ditiru (di depan pintu ruang penonton) (Neufert, $2002: 137$ ).

\section{b) Opera}

Opera adalah bentuk sandiwara panggung yang dinyanyikan seluruhnya atau sebagian dengan iringan band atau musik instrumental (KBBI online). Menurut (Neufert, 2002: 137), gedung opera ditandai oleh musik orkestra dan jumlah kursi (1000 hingga hampir 4.000 kursi) antara ruang penonton dan panggung. Ada ruang yang jelas di dalam gedung, dan sistem yang cocok dengan kursi tidak terpengaruh oleh Pembatasan (tertutup) atau balkon penting untuk khalayak luas.

\section{c) Cinema}

Cinema atau Bioskop adalah pertunjukan yang menggunakan gambar (film) yang disorot oleh lampu untuk bergerak (berbicara) (KBBI, 2006: 125). Pada saat yang sama, menurut (Poerwadarminta, 1976: 303), bangunan mengacu pada gedung kantor (rumah), yang merupakan tempat pertemuan / tempat untuk menampilkan prestasi artistik, sehingga dapat disimpulkan bahwa gedung bioskop digunakan sebagai tempat untuk menampilkan pertunjukan film.

Fungsi dari gedung pertunjukan, gedung pertunjukan itu berbanding lurus dengan pertunjukan, tetapi dengan perkembangan zaman dan teknologi, ada banyak gedung teater multi-fungsi, seperti ruang serbaguna dengan fungsi ruang serbaguna, konser musik, dan ruang pertunjukan publik dengan fungsi kinerja teater.

Tujuan pembangunan gedung pertunjukan ini biasanya karena kurangnya hiburan di tempat atau kota, dan juga mempromosikan atau mengakomodasi seniman lokal untuk mengeksplorasi kreativitas dan bakat. Bangunan pertunjukan biasanya dibangun di pusat kota dan mudah untuk dipertimbangkan dalam hal memperoleh / menarik dan menarik khalayak (Neufert, 2002).

\section{Metode Penelitian}

Penelitian ini menggunakan tipe penelitian deskriptif dan kualitatif. Penelitian kualitatif dan deskriptif ini menghasilkan data deskriptif dalam bentuk tulisan di sekitar orang atau kata-kata dan fakta yang mereka lihat dan lihat. Jenis penelitian ini juga merupakan jenis penelitian dengan sistem melihat fakta-fakta maupun ilustrasi suatu keadaan yang ada dan kemudian dianalisa dengan mendeskripsikan serta mengidentifikasikan setiap aspek yang ada. (dalam Subandi, 2011)

Metode yang digunakan dalam penelitian ini adalah metode studi kasus (Case Consider). Metode ini berfokus pada objek tertentu dan dipelajari sebagai kasing. Penelitian ini berlokasi di Theater IMAX Keong Emas, TMII. Waktu penelitian ini dilakukan pada tanggal 24 Oktober 2019 dengan fokus pada objek bangunan yang sudah ditentukan. Penelitian yang dilakukan yaitu mengkaji mengenai bentuk bangunan Theater IMAX Keong Emas yang berdasarkan konsep arsitektur semiotik. 


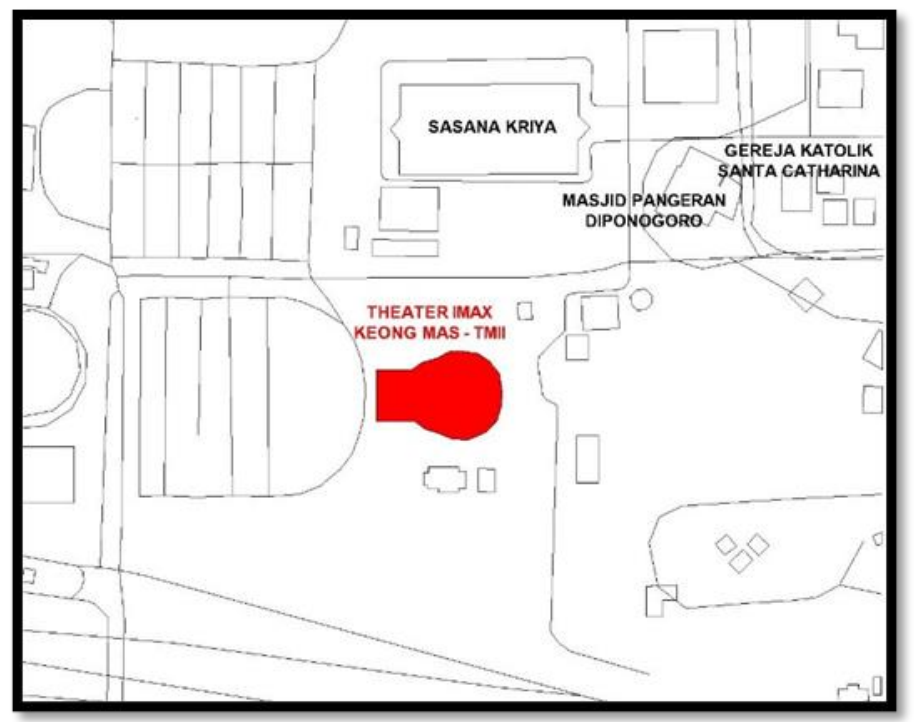

Gambar 1. Lokasi Theater IMAX Keong Emas

Sumber : Dokumentasi Pribadi, 2019

Semiotik Tanda Indeks merupakan simbol yang mewakili sumber referensi dengan mewakili atau menautkan ke sumber referensi lainnya.

Analisis penelitian ini dilakukan melalui teori observasi dan observasi semiotik Tanda Indeks secara berjenjang lingkupnya, mulai dari lingkup lingkungan, lingkup tapak bangunan, dan lingkup bangunan bagian luar maupun dalam.

\section{Hasil dan Pembahasan}

Berdasarkan pengamatan secara langsung didapatkan hasil dan pembahasan yang menitik beratkan pada tanda-tanda semiotik indeks yang muncul pada bangunan Theater IMAX Keong Emas dengan cara berjenjang lingkupnya adalah sebagai berikut :

\subsection{Analisis Bangunan Keong Emas dari Lingkup Lingkungan}

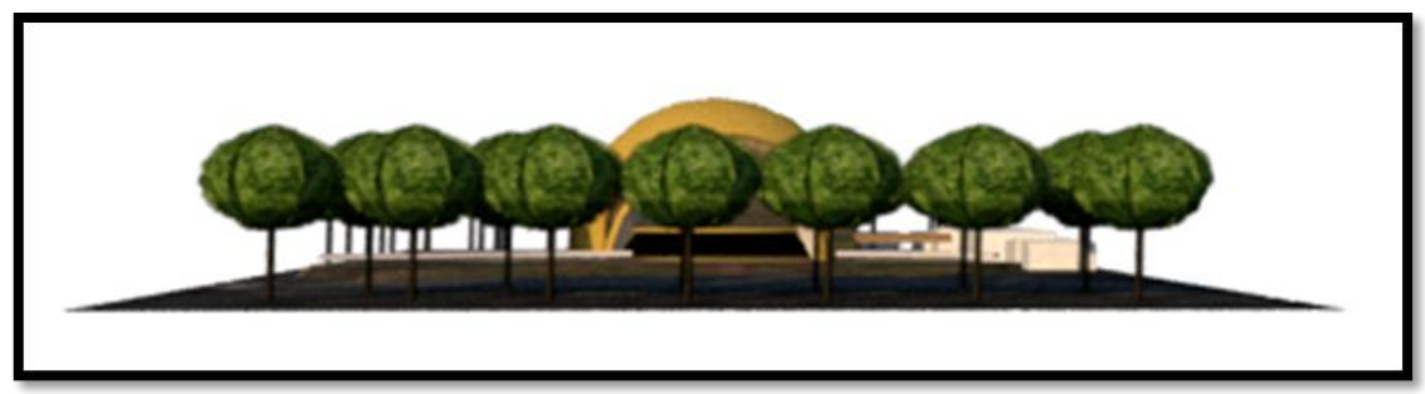

Gambar 2. Lingkup Lingkungan Theater IMAX Keong Emas Sumber : Dokumentasi Pribadi, 2019

Seperti yang dilihat pada gambar diatas, bentuk gubahan yang terbilang unik pada bangunan Keong Emas dapat terlihat dari jarak yang jauh. Hal ini dikarenakan area sekitar bangunan Keong Emas ini bukanlah bangunan-bangunan yang menjulang tinggi seperti gedung-gedung perkantoran, melainkan hanya pohon-pohonan yang tumbuh tinggi keatas.

Bentukan bulat pada bagian atas bangunan Keong Emas (Representamen) merupakan suatu tanda indeks dari keberadaan suatu bangunan besar yang mempunyai bentuk gubahan unik serta warna yang mencolok dan mengundang banyak perhatian pengunjung walau hanya sekedar melintas saja (Objek). Dengan melihat dari kejauhan, dapat dipastikan setiap pengunjung yang melintasi bangunan tersebut akan merasakan rasa penasaran dan keingintahuan dengan apa yang sebenarnya ada dibalik pepohonan yang tumbuh tersebut. 


\subsection{Bangunan Keong Emas dari Lingkup Tapak Bangunan}

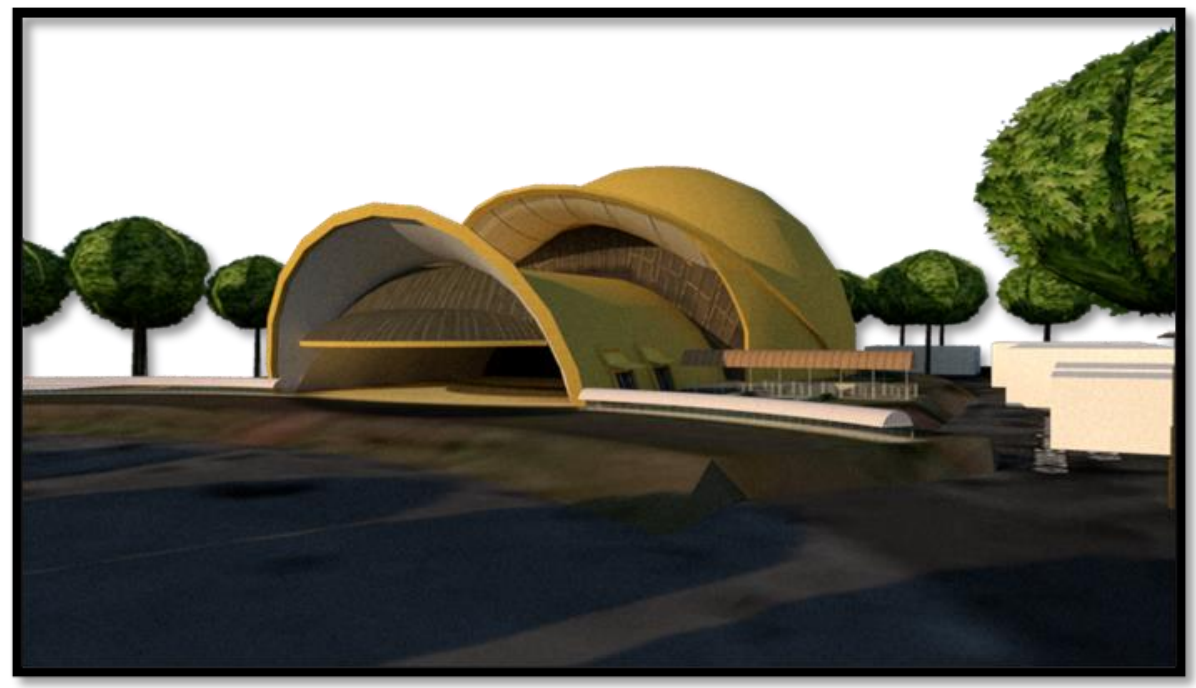

Gambar 3. Lingkup Tapak Bangunan Theater IMAX Keong Emas Sumber : Dokumentasi Pribadi, 2019

Seperti yang dilihat pada gambar diatas, bangunan gedung yang bervolume besar dengan bentuk menyerupai cangkang keong yang terbilang unik ini, memberikan kesan rasa keingintahuan setiap pengunjung yang datang tentang suatu kegiatan besar apa yang dilakukan di dalam bangunan yang bervolume besar tersebut. Terlebih bangunan IMAX Keong Emas ini mempunyai warna yang mencolok yaitu warna emas dan pastinya mengundang perhatian pengunjung yang ada maupun yang hanya sekedar melintas.

Bentuk unik yang menyerupai cangkang keong dengan warna mencolok emas (R) merupakan suatu tanda indeks dari rasa keingintahuan para pengunjung terhadap fungsi dari bangunan Keong Emas tersebut (O). Sedangkan bentuk gubahan bulat dengan volume yang terbilang cukup besar itu (R) merupakan bentuk tanda indeks dari bangunan yang mengadakan suatu jenis kegiatan dan mampu sekiranya menampung jumlah pengunjung yang sangat banyak $(\mathrm{O})$.

\subsection{Analisis Bangunan Keong Emas dari Lingkup Bangunan Bagian Dalam}

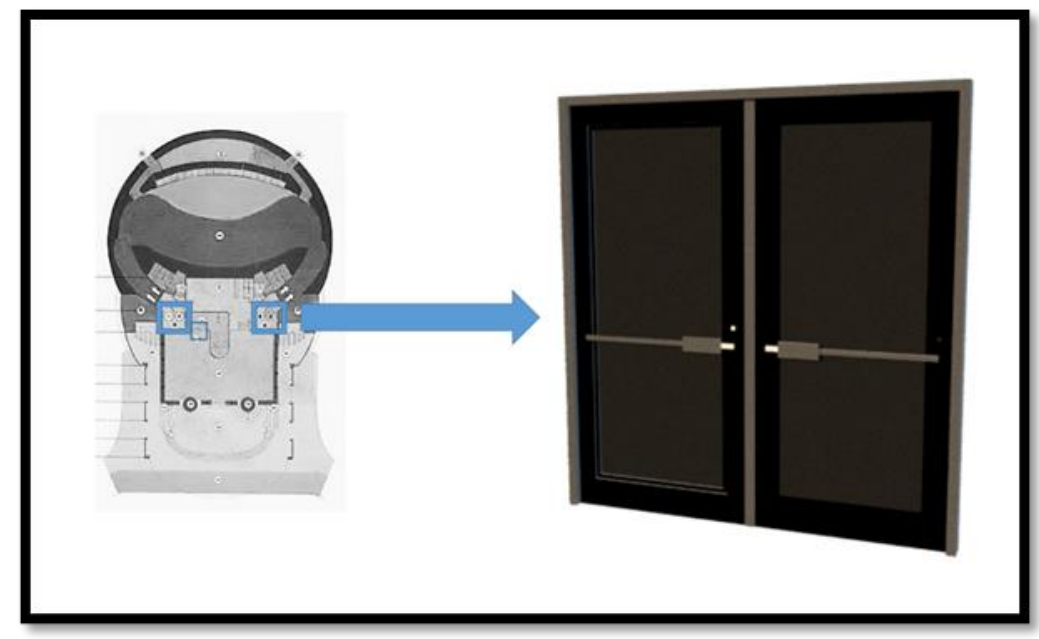

Gambar 4. Pintu Masuk Ruang Utama Theater IMAX Keong Emas Sumber : Dokumentasi Pribadi, 2019

Seperti yang dilihat pada gambar diatas, terdapat pintu masuk ruang utama pada bangunan Keong Emas yang berjumlah dua buah pada sisi kanan dan kiri, dua buah pintu keluar pada sisi kanan dan kiri pula serta satu buah pada bagian tengah sebagai pintu masuk lewat jalur VIP. Pintu utama tersebut menggunakan 
material tambahan berupa peredam suara yang mana merupakan salah satu pilihan sebagai penambah estetika dalam segi akustik.

Pintu masuk utama dengan double door yang terlihat elegan dengan paduan material tambahan sebagai peredam suara $(R)$ merupakan bentuk tanda indeks dari keberadaan ruang utama pemutaran film-film yang akan di tayangkan dan mampu menampung para pengunjung dengan jumlah kuota yang sudah ditentukan $(\mathrm{O})$.

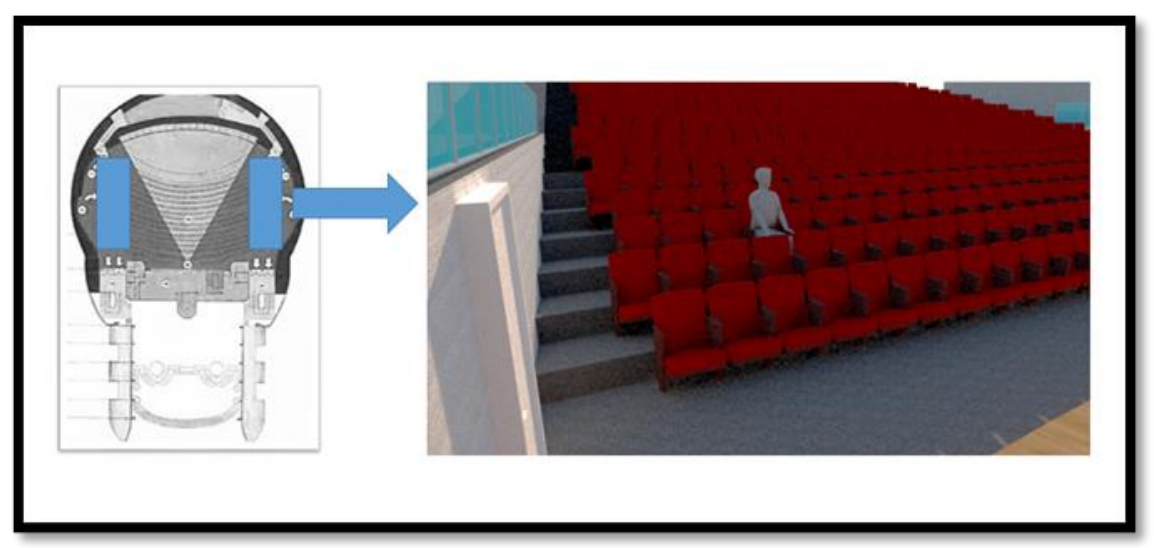

Gambar 5. Tangga pada Ruang Utama Theater IMAX Keong Emas Sumber : Dokumentasi Pribadi, 2019

Pada gambar diatas, jumlah tangga pada ruangan utama pemutaran film hanya berjumlah dua buah, yaitu pada sisi bagian kanan dan sisi bagian kiri ruangan tersebut. Tangga tersebut digunakan penonton untuk naik dan mencari tempat duduknya yang sesuai sekaligus tangga tersebut mengarahkan setiap penontonnya menuju pintu keluar ruang utama yang berada di lantai dua bangunan Keong Emas.

Dapat dilihat terdapat dua anak tangga $(\mathrm{R})$ dalam gambar yang terletak pada bagian sisi kanan dan kiri ruang utama bangunan gedung Keong Emas. Keberadaan tangga tersebut merupakan bentuk dari tanda indeks bahwasanya terdapat banyak tingkatan lantai dan terdapat banyak tempat duduk yang bisa digunakan setiap penonton yang datang $(\mathrm{O})$ pada ruang utama pemutaran film di gedung bangunan Keong Emas.

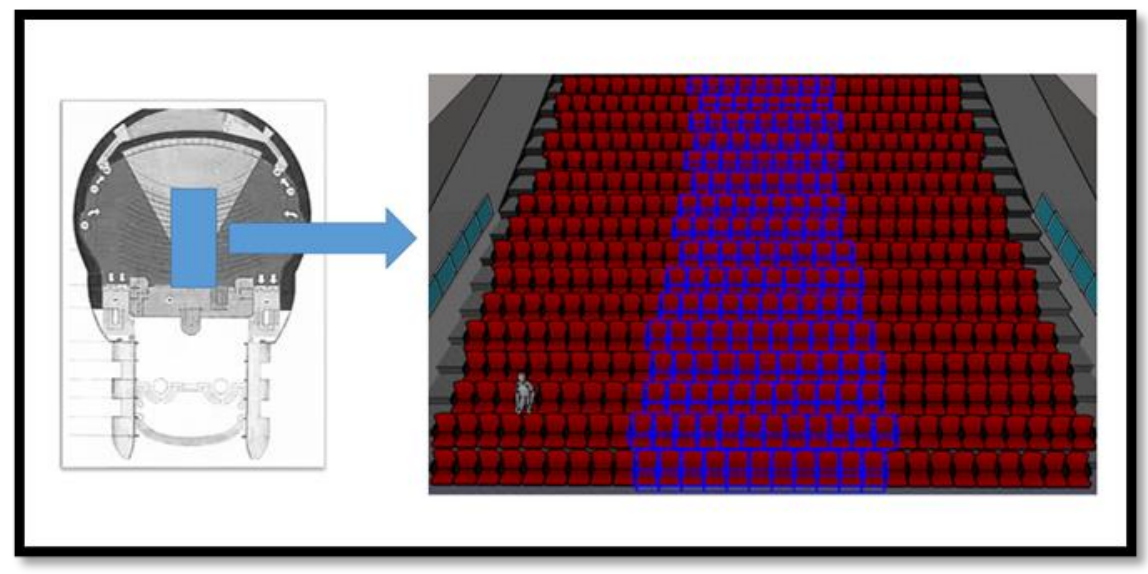

Gambar 6. Kursi pada Ruang Utama Theater IMAX Keong Emas Sumber : Dokumentasi Pribadi, 2019

Dari data yang di dapat, jumlah kursi untuk penonton regular sebanyak 811 kursi dan 36 kursi untuk penonton VIP. Untuk penonton VIP sudah jelas posisi tempat duduk yang diberikan adalah dengan posisi yang ternyaman dan terbaik. Sedangkan untuk penonton regular, tempat duduk yang diberikan tergantung dengan selera kenyamanan para penonton itu sendiri. Namun terdapat perbedaan warna antara kursi bagian tengah dengan kursi-kursi yang ada pada bagian samping. Pada beberapa kursi bagian tengah terlihat berwarna biru, sedangkan kursi pada bagian samping tetap terlihat dengan warna merah.

Seperti yang dapat dilihat, perbedaan warna biru pada kursi di bagian tengah ruang utama pemutaran film (R) merupakan bentuk tanda indeks dari kursi-kursi yang mempunyai point of view ternyaman atau posisi duduk untuk menonton film yang nyaman untuk penonton regular di ruang utama pemutaran film $(\mathrm{O})$. 
Konsep arsitektur simbolik, terutama tanda indeks, adalah simbol yang mewakili referensi dengan menunjukkan referensi atau menghubungkan ke referensi lain. Atribut dari tanda indeks tergantung pada keberadaan simbol, atau hanya berhubungan dengan konten yang mereka wakili. Tanda indeks juga merujuk ke lokasi atau ruang, objek, makhluk, dan peristiwa yang terkait dengan penggunaan tanda.

\section{Kesimpulan}

Semiotik Tanda Indeks dapat diamati dari beberapa lingkup jenisnya yaitu : mulai dari lingkup lingkungan, lingkup tapak bangunan, lingkup bangunan bagian luar maupun dalam, dan lingkup elemen bangunan. Penerapan konsep arsitektur semiotik Tanda Indeks pada bangunan gedung pertunjukan yang telah dikaji mempunyai bentuk tanda-tanda indeks yang muncul dan terlihat pada setiap jenis lingkupnya seperti :

- Lingkup Lingkungan : tanda indeks yang muncul pada lingkup lingkungan hanya didapat pada bentuk bangunan dari Theater IMAX Keong Emas yang menjulang tinggi dengan bentukan yang terbilang unik. Dan juga dikarenakan di area sekitar bangunan Keong Emas tersebut tidak ada bangunan-bangunan lainnya seperti gedung-gedung yang tinggi sehingga membuat bangunan tersebut nampak jelas apabila dilihat dari kejauhan. Bentuk bangunan yang besar disertai dengan kondisi lingkungan yang bebas dari keberadaan gedung-gedung tinggi membuat terjadinya kemunculan tanda-tanda indeks pada gedung pertunjukan.

- Lingkup Tapak Bangunan : tanda indeks muncul pada setiap studi kasus yang telah diteliti. Pada setiap studi kasus mempunyai bentukan volume bangunan yang terbilang cukup besar. Hal ini tentu yang menarik perhatian setiap pengunjung yang datang terlebih setiap studi kasus mempunyai bentuk tapak dengan konsep masing-masing yang menarik perhatian pula. Bentuk massa bangunan yang besar dengan bentuk tapak yang menarik perhatian, membuat munculnya tanda-tanda indeks pada gedung pertunjukan.

- Lingkup Bangunan : tanda-tanda indeks yang muncul pada lingkup bangunan terjadi pada setiap studi kasus yang diteliti. Tanda indeks pada setiap studi kasus tergantung dengan kebutuhan ruang-ruang pada setiap gedung pertunjukan. Munculnya tanda indeks pada luasan bangunan internal dan eksternal mengacu pada posisi atau ruang, objek, peristiwa, dan kegiatan, yang diwakili oleh tanda indeks yang terdapat di setiap bangunan gedung pertunjukan.

- Lingkup Elemen Bangunan : tanda-tanda indeks yang muncul pada lingkup elemen bangunan hanya muncul pada ruangan utama di setiap gedung pertunjukan dan terjadi pada setiap studi kasus yang diteliti. Tanda indeks pada lingkup elemen bangunan ini menjelaskan mengenai fungsi lain dari sebuah elemen yang ada di setiap ruangan utama gedung pertunjukan.

\section{Referensi}

Ahmad, F. B. (2016). Makna Hidup Iklan Rokok di Televisi (Analisis Semiotika John Fiske Terhadap Iklan Rokok "A Mild Go Ahead versi Langkah 2016") . Universitas Telkom .

Albar, M. W. (2018). ANALISIS SEMIOTIK CHARLES SANDER PIERCE TENTANG TAKTIK KEHIDUPAN MANUSIA : DUA KARYA KONTEMPORER PUTU SUTAWIJAYA . Lensa Budaya, $123-136$.

Alireza Ghafari, M. M. (2015). Evaluation the Theories of Semiotics Approach in the Reading of Architecture and Urbanism. JK Welfare \& Pharmascope Foundation | International Journal of Review in Life Sciences, 642-649.

Anggriawan, F. (2016). ANALISIS SEMIOTIKA WACANA IKLAN SABUN MANDI DAN SAMPO PADA MAJALAH BOBO. UNIMED.

Anusha.V.S, G. B. (2019). Movie Posters of Bollywood Remakes: A Semiotic Analysis . International Journal of Innovative Technology and Exploring Engineering (IJITEE) , 291-301.

Ashadi. Kajian Makna Dalam Arsitektur Dan Paham-Paham Yang Memengaruhinya. Jakarta: Arsitektur UMJ Press , 2018.

Dariwu, Claudia T. "Kajian Semiotoka Dalam Arsitektur Tradisonal Minahasa." t.thn.: 21-22.

Ekomadyo, Agus S. "Pendekatan Semiotika Dalam Kajian Terhadap Arsitektur Tradisional Di Indonesia ." Seminar Nasional Naskah Arsitektur Nusantara: Jelajah Penalaran Arsitektural , 9 September 1999 : 23.

Enung Nurjanah, S. L. (2018). TINJAUAN SEMIOTIKA PUISI IBU INDONESIA KARYA SUKMAWATI SOEKARNOPUTRI. Parole (Jurnal Pendidikan Bahasa dan Sastra Indonesia) , 283-290. 
Fatima, A. A. (2019). REPRESENTASI NILAI KEBANGSAAN DALAM FILM SOEKARNO (Analisis Semiotika John Fiske). IAIN Purwokerto.

G.J. Allan, D.E. and Dorothy. Community and Community Development. Hague: Mounton \& Co, 1976.

Halina Sendera Mohd. Yakina, A. T. (2014). The Semiotic Perspectives of Peirce and Saussure: A Brief Comparative Study . Procedia - Social and Behavioral Sciences , 4-8.

Jansz, Paul Cobley dan Litza. Mengenal Semiotika for Beginners. Bandung: Mizan, 2002.

Neufert. Data Arsitek Jilid II Edisi 33. Jakarta: PT. Erlangga, 2002.

Nuri Dwi Vindriana, S. M. (2018). POLITIK KEBUDAYAAN DALAM NOVEL SINDEN KARYA PURWADMADI ADMADIPURWA: KAJIAN SEMIOTIKA ROLAND BARTHES . Garuda, 10-22.

Pateda, Mansoer. Semantik Leksikal. Jakarta: Rineka Cipta, 2001.

Putu Krisdiana Nara Kusuma, I. K. (2017). ANALISIS SEMIOTIKA ROLAND BARTHES PADA RITUAL OTONAN DI BALI . Jurnal Manajemen Komunikasi, 195-217 .

Rana Akbari Fitriawan, A. P. (2016). MAKNA HIDUP IKLAN ROKOK DI TELEVISI (Analisis Semiotika John Fiske Terhadap Iklan Rokok A Mild Go Ahead versi Langkah 2016) . e-Proceeding of Management, 3713-3723.

Rifanda, P. G. (2019). SEMIOTIKA FOTO JURNALISTIK PEMAKNAAN INTERAKSI SOSIAL BENCANA ALAM (Analisis Semiotika Roland Barthes Dalam Kumpulan Foto Jurnalistik Karya Ulet Ifansasti Dalam Media Getty Images). Universitas Pembangunan Nasional Veteran Yogyakarta.

Rina Saraswaty, A. M. (2016). KAJIAN MENTAL IMAGE MAHASISWA ARSITEKTUR TERHADAP ARSITEKTUR DENGAN METODE PENDEKATAN SEMIOTIK. EDUCATION BUILDING , 14-20.

Sannie, A. N. (2018). ANALISIS SEMIOTIKA MAKNA KESENDIRIAN PADA LIRIK LAGU "RUANG SENDIRI" KARYA TULUS . Garuda, 41-51.

Sobur, Alex. Semiotika komunikasi. Remaja Rosdakarya, 2003.

Suherdiana, D. (2008). KONSEP DASAR SEMIOTIK DALAM KOMUNIKASI MASSA MENURUT CHARLES SANDERS PIERCE . Jurnal Ilmu Dakwah, 371-407.

Utami, R. (2013). Nilai Budaya Palembang dalam Tari Gending Sriwijaya (Analisis Semiotika Roland Barthes dalam Lirik dan Gerak Tari Gending Sriwijaya) . TEBS Library \& Knowledge Center, Ilmu Komunikasi .

Yanti Dwi Yuliantini, A. W. (2017). SEMIOTIKA DALAM NOVEL REMBULAN TENGGELAM DI WAJAHMU KARYA TERE LIYE. $J u$ r $n$ a l L $i$ t e r a s $i, 65-72$.

Yuwono, T. Christomy dan Untung. Semiotika budaya. Jakarta: Pusat Penelitian Kemasyarakatan dan Budaya UI, 2004. 